\title{
Christian Tagsold
}

\section{Popular realms of memory in Japan: the case of Sakamoto Ryōma}

\begin{abstract}
Sakamoto Ryōma is said to have united the fiefs of Satsuma and Chōshū in their attempt to overthrow the Tokugawa shogunate, which eventually led to the Meiji Restoration. He is one of the most popular historical figures in contemporary Japan. However, while the remembrance and commemoration of the darkest decades from the 1930s to the 1940s in Japanese history have been researched extensively in the West, cases such as Sakamoto have been mostly neglected. This paper examines Sakamoto's current popularity and puts it into the context of Pierre Nora's concept of "realms of memory." Nora's concept describes how national identity draws upon various memories and transforms them into interconnected points of reference. The analysis starts by scrutinizing on the many historical novels that have been written about Sakamoto as well as the historical TV drama Ryōma-den, produced and aired by public broadcaster NHK in 2010. Situating Sakamoto's case in the overall picture of Japanese "realms of memory" reveals the political dimensions of memorizing him. Sakamoto has been cherished by conservatives and left-wing students alike. The paper concludes that Sakamoto and other heroes such as Saigō Takamori should be included into Western research on collective historical memory in Japan because they shed light on the complex entanglement of memory and politics in Japan.
\end{abstract}

Keywords: historical novels, realms of memory, Sakamoto Ryōma, Shiba Ryōtarō, Taiga drama

Christian Tagsold: e-mail: tagsold@phil.hhu.de 
日本におけるポピュラーな記憶の領域：坂本龍馬のケース

$$
\text { クリスティアン タークソルト }
$$

坂本龍馬は德川幕府を倒すために薩長同盟の締結を推進し、後の明治維新に影 響を及ぼした人物であると言われている。昨今、坂本龍馬は日本でもとても人 気のある歴史人物の一人である。しかし、欧米では日本史の中でも最も暗い時 代であった 1930 年代から 1940 年代に関する記憶やコメモレーションについて は西欧でも広範囲に研究されているにも拘らず、坂本龍馬のようなケースは殆 ど顧みられていない。本稿は現在の坂本龍馬人気を考察し、ピエール・ノラの 「記憶の領域」というコンセプトに沿って検証するものである。ノラのコンセプ トによるとナショナル・アイデンティティはさまざまな記憶から構築されてお り、個々の記憶は評価基準に沿って集約されるのである。

坂本龍馬の人気の分析は、まず龍馬に関する多数の歴史小説、そして2010年に 放映されたNHK大河ドラマ「龍馬伝」を詳しく検討することから始める。

坂本龍馬のケースを日本における「記憶の領域」という観点から見ると、坂本 龍馬の記憶は政治的にも残されるべきであることは明白である。坂本は保守的 な学生にも左派の学生にも人気がある。坂本龍馬、さらには西郷隆盛のような 人物は、西洋における歴史研究でも日本の難しい局面で打開の光を与えた人々 として、日本史の集合的記憶として取り上げられるべきであろう。

\section{Introduction}

Japan's state television organization NHK has been broadcasting annual historical fiction TV series called Taiga dorama ('drama of the great river') since 1963. They tell the stories of historical heroes or historical events, unfolding for 45 minutes every Sunday at primetime eight o'clock. Each series starts in January and ends after 50 episodes (or a few less) in December. In 2010, Sakamoto Ryōma was the hero of the year in the series called Ryōma-den. As always, the main character of the Taiga drama quickly turned into a public hero: many new books were published on Sakamoto; his native prefecture of Kōchi profited from tourism; and the famous photography of Sakamoto was ubiquitous, as was merchandise ranging from little plastic Sakamotos (modeled after the photography) to posters and pens. Furthermore, in a public poll conducted among 1,000 Japanese, $14 \%$ even answered that for them Sakamoto was the Japanese person most resembling Barack Obama (Hongo 27 April 2010).

Sakamoto Ryōma was one of the leading figures in the Meiji Restoration. As a young samurai from Kōchi he decided to devote his life to the cause of 
sonno-joi, that is, "bringing the emperor back to power and expelling the barbarians," as the Westerners who had flocked into the country since the opening of ports in 1854 were called. Sakamoto's main accomplishment within this movement was to unite the two fiefs of Satsuma and Chōshū. Both fiefdoms opposed the ruling Tokugawa shogunate, but they did not unite in this fight until Sakamoto intervened and helped form a crucial alliance to finally overthrow Tokugawa rule. This achievement alone would surely earn Sakamoto a lasting place in Japanese history books - albeit not a central one.

However, Sakamoto's contemporary popularity in Japan indicates clearly that he cannot be understood simply by his historical role in the late Edo period. Although he probably played an important part in the movement of young samurai fighting against the Tokugawa shogunate, his actual influence extends beyond his historical role. Sakamoto has stepped out of the history books to conquer the realm of popular culture. He is not the only historical figure to have done so. Alongside Sakamoto, figures such as Saigō Takamori, Tokugawa Ieyasu, the 47 rōnin (see Smith 2006), and others are also worth mentioning. They are all "present" in Japan today not only in novels, manga, anime, TV series such as the Taiga dorama, as well as many popular history books, but also on advertising posters and so forth. With their strong presence in mass media coupled with commodification through advertising and even fan merchandise, these historical figures have all found a place in Japanese popular culture.

Although Sakamoto and other historical figures are highly "visible" in Japan today, research on the role of history in contemporary Japan has rarely scrutinized such phenomena - and this is especially true for Western research on Japan. In contrast, Japanese historians and literary critics have long studied this type of "public memory," as this paper will show. ${ }^{1}$ One of the few exceptions in Western research is a paper by Henry Smith (2007) examining the popularity of Sakamoto in Kyoto. The paper was published in a volume dedicated to historian Marius B. Jansen, author of the most widely read account of Sakamoto's life in English, written more than half a century ago (Jansen 1961). This neglect of public memory is surprising when one looks at the prominence of historical figures such as Sakamoto.

The analyses of Japanese memory and history by Western researchers have focused mainly on how the era from the 1930s to 1945 is presented in public

1 One of the main approaches in Japan has been to analyze historical novels (rekishi shōsetsu) about heroes such as Sakamoto. The genre has brought forth many bestsellers, including Tokugawa leyasu by Yamaoka Shōzo and Saka no ue no kumo by Shiba Ryōtarō, among many others. Historical novels are among the best-selling books in Japan. 
discourse and how it forms a part of commemorative practice. ${ }^{2}$ This focus is understandable since the memory of Japanese ultra-nationalism, cruel warfare, and wartime atrocities is strongly contested. Conservatives cherish their visits to the Yasukuni Shrine, where not only the fallen "heroes" of the Imperial Japanese Army are revered but also generals who were charged with war crimes at the Tokyo Trials in the late 1940s. Especially visits by prime ministers on August 15 - the commemoration of the end of the war, as the day of Japanese surrender is officially labeled - are a hot topic both in Japan and overseas. Other public memories that have been analyzed in depth include Hiroshima, the Nanjing Massacre, and the ianfu, that is, women who were forced into prostitution by the Imperial Japanese Army. Of course, the focus of Western research on this part of historical memory in Japan is very important, not least because Japan's relations with its Asian neighbors are severely hampered by many of these memories; however, owing to this focus, seemingly less contested memories have been neglected.

In this paper, I attempt to close this gap in the analysis of collective popular memory in Japan, at least for the example of Sakamoto Ryōma. The aim is to show that such forms of popular memory are nonetheless connected to the above-mentioned "realms of memory" in Japan. They are also contested and political, though on the face of it not as much as other memories connected to "hotspots" such as Yasukuni Shrine. However, for a better understanding of the contemporary significance of history in Japan, historical heroes such as Sakamoto Ryōma should not be ignored.

My analysis is based on French historian Pierre Nora's influential concept of "realms of memory" (lieux de mémoire) (Nora and Kritzman 1996, 1997, 1998). As a conceptual framework, the idea of "realms of memory" helps situate Sakamoto within the wider context of Japanese memory. Therefore, how Japan and the case of Sakamoto fit into the framework developed by Nora will first be explained. Next, Sakamoto's posthumous popularity will be examined to explain how memory is fed by writers of historical novels, historical TV drama, and manga series, as well as other media of popular culture. This leads to the question of how the model of Sakamoto is applied in real life - and it is applied by many people to a surprising degree. Finally, it will be shown how Sakamoto as a "realm of memory" is connected to those realms of memory that are more often the topics of Western research.

2 Among the influential books on this topic, Dutch journalist lan Buruma's (1994) Wages of Guilt has to be mentioned. In Germany, Brandt et al. (2003) have edited a widely read book on memory in Germany, Italy, and Japan. 


\section{Sakamoto as a realm of memory}

The analysis of contested memories related to Japanese ultra-nationalism, warfare, and wartime atrocities between 1931 and 1945 has intensified in the last three decades. Many books have been written about the contemporary significance of these hotspots of memory - research that has been connected to different theories of historical memory and identity. Recently, Sven Saaler and Wolfgang Schwentker (2008) have attempted to apply to Japan one of the most successful approaches to public memory. In the foreword to The Power of Memory in Japan, they argue for the application of Pierre Nora's framework of realms of memory to Japan, and regard the papers in their book as a first step toward this goal (Saaler and Schwentker 2008: 6).

Pierre Nora's multi-volume series Les lieux de mémoire (published in France between 1984 and 1992) seeks to explore French realms of memory; and although lieu literally means 'site', the concept of lieux is in no way limited to actual geographical sites. For Nora, Reims as the "city of coronation" is a lieu (Le Goff 1998), and so are Joan of Arc (Winock 1998), the French national anthem "La Marseillaise" (Vovelle 1998), and Marcel Proust's À la Recherche du Temps Perdu (Compagnon 1997) - an enumeration that in itself shows Nora made use of some of the most renowned French historians to analyze these sites. Originally, the notion of lieu refers to the technique of Greek orators, who memorized their speeches by walking through an imaginary house (see Pfister 2011) in which each remarkable spot was connected to a part of the speech, thereby acting as an aide-memoire.

The construction of national memory is similar to this "house" filled with remarkable and memorable spots. However, realms of memory are not given or natural, but instead are introduced into modern society through deliberate acts of remembering mediated by "museums, archives, cemeteries, festivals, anniversaries, treaties, depositions, monuments, sanctuaries, fraternal orders" (Nora 1989: 12). Reading through the various lieux de mémoire in Nora's volumes, one can safely add to the list scholarly and non-scholarly books, schoolbooks, movies, and many other forms of media. Thus, agency for creating lieux is embedded in discourses on national history that replace "traditional memory," as Nora (1989: 12) calls spontaneous and ritualized memory of the premodern era in a somewhat romantic vision.

The strength of Nora's concept, thus, lies in the in-depth look at a variety of heterogeneous stories that together form realms of memory. Nora's work has not only been translated into various languages (including Japanese), it has also been adapted highly successfully to explore realms of memory in Germany, Italy, the Netherlands, and several other countries. The three volumes of the 
Deutsche Erinnerungsorte (François and Schulze 2001), for example, were welcomed by historians and pundits alike. As for the case of Japan, a first adaptation of Nora's concept is presented in Saaler and Schwentker's edited volume on lieux de mémoire in Japan. However, in this adaptation, the breadth of Nora's concept is reduced drastically in scope, as most of the papers deal only with the (historically) "critical” time span between 1931 and 1945.

The framework of Pierre Nora's concept offers a path to connect not only realms of memory such as the Yasukuni Shrine, the Nanjing Massacre, and ianfu, but also seemingly more "innocent" realms of memory such as Sakamoto Ryōma - even though Saaler and Schwentker's adaptation for the analysis of Japanese realms of memory seems to suggest otherwise. The German version of realms of memory, the Deutsche Erinnerungsorte by François and Schulze (2001) makes this clear. Although the time from the 1920s to 1945 and beyond surely forms an all-important focus of German history, this time span seems to occupy only a limited space in the three volumes and in their analysis of the German "house of memory." Of course, realms of memory such as Auschwitz and Hitler's bunker (Führerbunker) directly confront how National Socialism has been treated in German political and popular discourses since 1945; however, most realms of memory in the Deutsche Erinnerungsorte deal with other topics. Famous poets such as Goethe and Heine are part of it, as are the German system of social security and the football league (Bundesliga). But hardly any German realm of memory was unaffected by National Socialist interventions; in fact, most realms are influenced by this period and ideology in one way or another.

The poet Heinrich Heine is an excellent example to illustrate this (see Werner in François and Schulze 2001: 484-502). Though he lived in the nineteenth century, the question of how he was remembered is deeply entangled with National Socialism. Because Heine was a left-wing intellectual, lived most of his life exiled in Paris, and - most important of all - was Jewish, he was banned from official state memory in 1933 (Werner 2001: 495-496). As a consequence, Heine was mostly forgotten in West Germany after 1945. In contrast, the East German official ideology of memory cherished him as a true hero (2001: 496-497). This example clearly demonstrates how Nora's notion of memory helps to uncover how a single realm is related to the inventory of the national house of memory. National Socialism and even older forms of Kaiserreich anti-Semitism, as well as the division of Germany during the Cold War era, are important for understanding how Heine was remembered after his death.

The lessons from the example of Heine can be applied, albeit indirectly, to Sakamoto and the popular strand of Japanese history, as it shows potentials in analyzing how historic persons are turned into realms of memory. Whereas Heine has always been a hero of liberals and left-wingers, and at the same time 
a provocation for more conservative-leaning intellectuals, Sakamoto's case is more multilayered. His place in Japanese memory is volatile and, therefore, also sheds light on how historical heroes function. Furthermore, Sakamoto's story stretches farther into the present than that of Heine, who today is accepted more or less univocally as a great writer of his times and, therefore, is not so "present" anymore in public discourse, except in literary studies and commemorative events.

Nora's framework is not a meticulously elaborated theory that would give clear guidance on how to analyze and reframe each and every realm of memory. Rather, the framework was developed over more than a decade through the collection of more and more "realms" for publication in upcoming volumes. In the foreword of each of the seven volumes, Nora expanded the scope of the concept, thus gradually changing the notion of lieu de mémoire. But nowhere did Nora offer clear-cut tools for analysis. Therefore, it would not be necessary to invoke Nora at all if it was only for analyzing the memory of Sakamoto in Japan without looking beyond this singular case. Yet the strength of the many realms of memory brought together by Nora is that they illustrate how all the singular realms fit into and are part of the huge "house of memory" that constitutes the national identity.

\section{Novel Sakamoto}

Sakamoto Ryōma occupies a lasting place in Japanese memory. He first gained popularity at the beginning of the twentieth century and has been remembered vividly ever since. This realm of memory has been built on a variety of media, including movies, museums, statues, and merchandise. However, the development of Sakamoto's popularity can be traced most easily by analyzing historical novels, which are more or less an accurate depiction of his life. Three reasons speak in favor of this approach. First, there has been a constant flow of novels about Sakamoto for more than 100 years, making it easy to pinpoint changes in the interpretation of his historical role through the years. Second, several of these novels have been adapted to other media such as television, and thus form a solid basis for studying the phenomenon of Sakamoto in Japanese popular culture. Third, many Japanese historians, literary scholars, and pundits have written about historical novels and their significance for public memory. The most influential novel about Sakamoto was written by Shiba Ryōtarō, arguably the most famous author of historical fiction in Japan. The novel attracted substantial attention by critics to the role of samurai in Japanese history. 
Looking at historical novels also entails tapping into the rich discourse on the genre, providing valuable commentary on Sakamoto's role in literature. In 1976, the left-wing literary pundit Ozaki Hotsuki published an influential study on historical novels. In 1986, the conservative historian Aida Yūji, a famous proponent of nihonjinron, added his book about how to read historical novels through a discussion of the works of five of the most important authors of historical novels. Furthermore, in his book Rekishi no hōhō, historian Irokawa Daikichi (1992), famous through his long-lasting fight for schoolbooks that admit more explicitly Japanese atrocities during the war, stressed the importance of popular history in general, and the NHK TV Taiga dramas in particular, for shaping popular notions of history in Japan. Hakoishi Hiroshi (1994), a historian specializing in the late Edo period and Meiji Restoration, also used this argument for the case of Sakamoto Ryōma in an issue of the journal Rekishi Hyōron dedicated to literature and manga interpretations of Japanese history. And historians Narita Ryūichi (2003, 2009) and Nakamura Masanori (2009), who, in their studies, critically re-read Shiba Ryōtarō's novels, also deserve mentioning. ${ }^{3}$

In 1988, Konishi et al. (1988: 360) had already counted more than fifty novels on Sakamoto. ${ }^{4}$ Since then, even more novels have been published. Obviously, Sakamoto has been a popular topic among Japanese authors of historical novels. The flow of novels can be divided into four distinct periods. In the late 1920s, eleven novels appeared, followed by another seven between 1941 and 1944. Sakamoto regained popularity in the 1950s and 1960s when new novels about Sakamoto started gradually to appear. A third Sakamoto boom started in the late 1960s and lasted throughout the 1970s, with up to four novels on Sakamoto being published in some years. Popularity carried on into the 1980s; however, since the treatment of Sakamoto changed decisively in this decade, I argue that the period of the 1960s to 1970s and the 1980s should be treated separately.

The first-ever novel about Sakamoto Ryōma came out long before the first boom started. Sakazaki Shiran's Kanketsu senri no koma ('The sweat and blood of a genius') was published in 1883 during the surge of the Liberty and Civil Rights movement (Jiyū minken undō). This movement tried to enforce the ruling

3 Of course, judgments on Shiba's account of Sakamoto especially were anything but unequivocal. While Narita and Nakamura are highly critical, and Hakoishi is to a lesser degree, Aida Yūji was full of praise for Shiba's writing.

4 The classification of novels, as proposed by Konishi et al. (1988), allows for some discussion on the categories. Some smaller novels might not meet strict definitions of literary studies. However, the list is very helpful as a rough guide to novels on Sakamoto. The basic treatment of the realm of memory is mirrored very well in this list. 
Meiji oligarchy to introduce a constitution and share power with the citizenry. To strengthen the political claims of the movement, Sakazaki depicted Sakamoto as an early forerunner of the fight for democracy and a constitutional monarchy (Ueda 2005: 67), a depiction that was all the more plausible because Sakamoto was a native of Kōchi. This province was at the center of Jiyu minken undō activities, with many of the movement's leading figures, including Itagaki Taisuke and Ueki Emori, having been born there. Kanketsu senri no koma was not really a historical novel but rather a political one. Ozaki Hotsuki (1976: 39) has argued that Sakazaki took up the life of Sakamoto as a topic because other political activities had been declared unlawful. Kaku Kōzō (1993: 20) added that Sakazaki's novel has been highly influential in forming the legend of Sakamoto.

The first real boom of novels about Sakamoto, which started in the late 1920s, stuck to the political interpretation of Sakazaki. It is here that Sakamoto turned into a genuine realm of memory. In other words, memories of Sakamoto were, henceforth, no longer spontaneous. Sakamoto would have probably been gradually forgotten if not for the novels and other forms of nostalgic retrospection so typical for the establishment of realms of memory as markers in quickly changing modern societies (Nora 1989: 12). However, the authors of the Sakamoto novels of the 1920s were no longer contemporaries as Sakazaki had been. Some of them, like Itō Chiyū (1930: 9), freely admitted that they had relied on Sakazaki for their interpretations of Sakamoto. It is thus not surprising that Sakamoto was depicted mainly as a pacifist and fighter for freedom, as Shimaoka (1965: 158) argued. This is very clear in a play written by Mayama Seika, in the preface of which Mayama (1928: 5) writes that Sakamoto "loudly laughed at militarism" and adhered to constitutionalism. Following the interpretation of Minobe Tatsukichi, ${ }^{5}$ for Mayama (1928: 131) "Imperial Japan is first of all a constitutional state." By then a historical figure, Sakamoto was thus interpreted as attesting to the democratic atmosphere of the Taishō period and the very first years of Shōwa. This boom of novels was also accompanied by movies; from 1911 to 1939, a total of 14 bore Sakamoto's name in their title, with most of them coming out in the late 1920s and early 1930s (Smith 2007: 105). In sum, Sakamoto was widely remembered and had become an icon of democracy.

However, in the 1930s, the tide turned completely. As the interest in democracy and pacifism vanished under ultra-nationalism and the rule of the military,

5 Minobe Tatsukichi was a professor of law at the Tokyo Imperial University. At the beginning of the twentieth century, he established the state organ theory, which claimed that the emperor was an organ of the people, not of the state. This theory of constitutional monarchy became the raison d'état for two decades. However, in the 1930s, the ultra-nationalists forced Minobe to step down and thus made very clear that they had a different idea about the position and role of the emperor. 
a new Sakamoto was propagated. Starting in 1941, seven novels depicted him as a naval hero serving the goals of war and Japanese hyper-patriotism. This was not without precedence. In 1904, the empress had reportedly dreamt of Sakamoto as a savior of the country in the raging war against Russia (Hakosihi 1994: 46). Newspapers took up the story and disseminated it. One of the authors to reanimate this interpretation was Hamamoto Hiroshi (1995 [1943]: 468), who, in his novel on Sakamoto, put it as follows: "It is a fact that Sakamoto Ryōma fought to establish an Imperial Navy. However, his successors did not follow him." He also argued that Sakamoto had founded a navy school in Kobe in order to defend neighboring Asian countries against Western imperialism - an anachronistic point that, nevertheless, must have made sense for readers in the 1940s. Hamamoto was a mariner himself and had been a journalist in Kōchi before the war.

The seven novels on Sakamoto that appeared in the early 1940s together form the dark spot in Sakamoto's "realm of memory." Authors used the popularity Sakamoto had gained during the 1930s as propaganda for the Imperial Navy, which had become pivotal for the fate of Japan in WWII through the attack on Pearl Harbor. While the war in China (which had effectively started in 1931, but which had fully taken off in 1937) centered on the advance of the Imperial Army, the new situation in the war calling for navy action after 1941 was now paramount in drawing the attention of the Japanese to the Navy and popularizing its actions. Instead of championing pacifism, Sakamoto was used as a call to arms. His story legitimized the arguments of the Japanese leaders advocating the Navy. Sakamoto was stripped of his revolutionary qualities and turned into a servant of the state and its propaganda. For readers of the earlier historical novels, this new interpretation might have been surprising. However, such reinterpretations are quite typical for realms of memory. Historical biographies allow for many different ways to retell a person's story since no life is completely without ambiguities and contradictions.

After Japan's defeat in WWII, Sakamoto was absent from new novels for more than a decade. Turning him into a naval hero had made him unacceptable for the postwar decade. Then, in 1956, Yamaoka Wakao wrote a new novel spanning three volumes that echoed the novels of the Taishō period and dumped Sakamoto's image as a war hero. However, the breakthrough came in the early 1960s, when Shiba Ryōtarō published Ryōma ga yuku ('Ryōma moves ahead') as a weekly serialization in the highly conservative national newspaper Sankei Shinbun from 1962 to 1966 and in the esteemed literary weekly Bungeishunjū starting in 1963. Shiba Ryōtarō was by far the most popular writer of historical novels (rekishi shōsetsu). He turned Sakamoto once again into a visionary democrat and pacifist, who not only wanted to unite Japan under the 
emperor but also started a shipping company called Kaientai. Shiba's Sakamoto was a perfect fit for a newly emerging Japan in the 1960s, as the country experienced rejuvenation and became a leading industrial nation. Bold and visionary heroes open to the world of trade and the influx of new knowledge to Japan were readily welcomed by readers of Shiba's Ryōma ga yuku. In addition, Shiba sketched Sakamoto as a champion of modernity, following Marius B. Jansen's (1961) account. By his own admission, Shiba had read Jansen intensively (see Hakoishi 1994: 47-48). In consequence, Shiba's reading of Sakamoto followed his general tendency to uncritically praise the Meiji period. As Nakamura (2009: 157) has pointed out, Shiba downplayed the continuity from the Meiji era to the Shōwa period, solely blaming developments in the latter for the political slide into ultra-nationalism that led to Japanese excesses in the 15 years that the war lasted.

Cleaning the Meiji period from any suspicion of continuity with the darkest period of modern Japanese history was an important precondition for turning Sakamoto, who - in Shiba's reading - had helped bring about modernity, into a true hero for the masses. Shiba Ryōtarō ignored the war hero in order to turn Sakamoto into a bright and untainted role model, and thus again proved Nakamura right. Furthermore, Shiba cleverly helped make Sakamoto accessible to readers by claiming that he had been a rather dull and unexceptional youth, and had even wet his bed until the age of twelve; however, using his own will and vision, Sakamoto had overcome his dullness as well as all obstacles placed before him. He left the fiefdom of Kōchi, became a rōnin, and acted as an entrepreneur with a political mission. Shiba stressed that "Ryōma's qualities help us living in the post-war era to see him very close to us" (Aida 1986: 178). Thus, thanks to Shiba, Sakamoto eventually became closer to the masses than anything between 1931 and 1945 managed to do. Through Ryōma ga yuku, which was published as an eight-volume book and became a major bestseller, Sakamoto was no longer just a historical person but almost a contemporary.

Even more importantly, the book was adapted into a TV series with 32 episodes in 1965 by the private TV channel MBS. But the real television breakthrough for Sakamoto was the Taiga drama of 1968 produced by NHK state television. Thus, Shiba's Sakamoto overcame the confines of historical novels and turned into a real television star. Since television had become the leading medium in the 1960s, Sakamoto obtained a new plasticity and was easier to identify with. By broadcasting him onto the screens of households nationwide, he became a more real figure than he had been in the rekishi shōsetsu. Since the Taiga dramas at times have audience ratings above $30 \%$, historian Irokawa Daikichi (1992: 10-11) has pointed out that they are very important for shaping the notion of history in Japan. 
This surely happened in the case of Sakamoto Ryōma, even though his Taiga drama had relatively low audience ratings. However, Hakoishi (1994: 50) has argued that the novels and the Taiga drama reached different audiences, the novel being read mostly by salarymen while their wives enjoyed the TV version. In any case, the airing of Ryōma ga yuku had a strong political background, as Hakoishi (1994: 49-50) has also shown: 1968 was the centennial of the Meiji Restoration and NHK produced many programs in this context, taking sides with Prime Minister Satō's approach to celebrate the centennial as a Japanese success story. Ryōma ga yuku fitted into the scheme very well due to the sturdy modernist stance Shiba had ascribed to his hero Sakamoto. Many historians disagreed with the overall pathos of the centennial, however, and protested against such uncritical reading of Japanese history.

Eventually, the Taiga drama nevertheless helped popularize Shiba's interpretation of Sakamoto, and it also helped raise sales of the original novel. Surprisingly, this was partly due to the fact that Ryōma ga yuku produced a very different reading among young left-leaning students who enjoyed both the novel and the Taiga drama. Because of the first drama's huge success, Ryōma ga yuku was turned into yet another historical television series. Finally, in 1982, the private TV channel Terebi Tōkyō aired its own twelve-hour version of Ryōma ga yuku. A profitable circle ensued: Enacting Ryōma ga yuku as a historical television series led to more books being sold, causing TV channels to take up the story again. Additionally, the three historical series were re-aired several times. Sakamoto had turned into a regular star on television, with political undertones due to the background of the Taiga drama in 1968 and the various interpretations given to both the novel and the TV series. He served left-wing students and right-wing politicians alike in backing up their claims about Japanese history.

Because of Shiba's Ryōma ga yuku and several other novels in the late 1960s and early 1970s, Sakamoto once again became a firmly established historical figure in the realm of literature, and treatments of his story started to diversify. While novels of the earlier Sakamoto hype had basically retold his biography, albeit with different interpretations, the new novels often concentrated on certain parts of the Sakamoto story. For example, some of them focused on Sakamoto's wives and thereby made him more accessible to a female readership; in addition, children's books also became popular.

In the fourth wave of Sakamoto novels, starting in the 1980s, new types of historical novels were published that worked with irony and postmodern techniques of pastiche. Outstanding examples of this approach are Tsuka Kōhei's two novels Bakumatsu junjō-den ('The story of the poor heart at the end 
of the Tokugawa era', 1990)6 and his three-volume Ryōma-den (1991, 1992, 1994). In the afterword to the first volume, both Tsuka (1991: 486) and the editor point out that the story is purely fictitious and any relation to real persons and events are coincidental. However, even readers who are only mildly attentive might have guessed that Sakamoto had probably never read Dostoyevsky's Crime and Punishment, as suggested by Tsuka, since it had been published only one year before Sakamoto's death and in Russian. Furthermore, in another part of the story, there are samurai taking nude photos and discussing contraception and condoms, and at the end of the three-volume novel, Sakamoto even opens a detective agency. All of this is only funny as parody because an image of Sakamoto had already been well established in the 1980s and 1990s. However, it also suggests that irony can be an important part of realms of memory (Niehaus and Tagsold 2012).

The 1980s not only saw Sakamoto turned into a parodistic historical character but also into a manga (Smith 2007: 108). O i! Ryōma started to appear in 1986 and was a long runner. The series appeared in the Weekly Young Sunday manga magazine for over ten years. The manga was also adapted as an anime by NHK in 1992/1993 and helped to attract many new, younger fans.

\section{Sakamoto enacted}

Sakamoto has not been confined to historical novels, TV series, and advertising campaigns. The various novels about Sakamoto Ryōma had a lasting effect on their readership. Aida Yūji (1986: 27) once stated that "Ryōma ga yuku served as an overwhelming reference for the strata of salariman.” Indeed, for a long time, salarymen probably formed the core readership of historical novels centering on heroes such as Sakamoto. Magazines for salarymen often published short pieces on historical heroes and stressed the adaptability of their strategies and experiences to the daily work of salarymen. This reading was normally rather a conservative one, falling more or less in line with what NHK had had in mind when choosing Ryōma ga yuku as template for a Taiga drama. However, the myth of the salaryman as the indispensable backbone of the Japanese economy has faded over the last few decades, and the appeal of a typical salaryman career has been somewhat tainted due to economic hardships caused by various internal and external crises.

6 The subtitle Sakamoto o kitta onna ('The woman who stabbed Sakamoto') is a pun on Sakamoto o kitta otoko by Saotome (1971). 
Sakamoto's appeal, however, has not suffered but simply changed to a certain degree. At any rate, it had not been limited to salaryman in the 1960s and 1970s; Sakamoto was also very popular with students and left-wing artists, thus overcoming a too-narrow fixation by conservative, and sometimes even nationalist, milieus. One of the most famous examples is probably Takeda Tetsuya, the lead singer of the folk group Kaientai, which was founded in 1972 and named after Sakamoto's trading company because Takeda had been a fan of Shiba's Ryōma ga yuku. Not only did Takeda draw a manga of Sakamoto, more than once he also modeled his pose on that of Sakamoto (Tagsold 2000), as on the cover of the band's Best Selection album. Takeda's haircut, pose, and look are clearly inspired by the most famous photographs of Sakamoto.

This enacting of Sakamoto Ryōma has not been limited to artists like Takeda. Amikura Toshimune (2010) has claimed that more than 130 Ryōma fan clubs exist across Japan. This nationwide scene of fan clubs reminds one very much of the examples of fandom described in William W. Kelly's (2004) Fanning the Flames. Fans and Consumer Culture in Contemporary Japan. While the fans in the contributions to Kelly's edited book are interested in contemporary phenomena such as sumo wrestling and pop groups, Sakamoto is long deceased, yet is still the target of fan culture. These ardent followers are part of the lieu de mémoire and, as such, shed another light on the uses of memory in Japan an aspect that is rarely dealt with in Western literature. In this context, Sakamoto is often interpreted as some sort of rebel against the boredom of everyday life. Surprisingly, Shiba's novel is cited as an important backbone in these quarters. Even if it was intended as a classical modernist tale of a hero overcoming pre-modernity, some readers have expanded the novel's message in their interpretation and have adapted it to their understanding of present problems.

In 2008, I visited a central Kyoto-based Sakamoto fan club that will serve as an example of this layer of Sakamoto's realm of memory. Finding the club was easy because its president runs a small bar called Ryōma. The president of the club and owner of the bar is another example of someone re-enacting Sakamoto Ryōma, not only dressing like Sakamoto but also adopting the same hairstyle and even certain gestures related to his hero. The bar itself was full of Sakamoto memorabilia. I interviewed the president along with some members, as well as some customers of the bar.

The president himself had become a Ryōma fan 15 years ago and remembered the exact day and occasion of this "conversion", though he did not disclose any further details in the interview. He had been a shop owner in a downtown shopping mall..$^{7}$ The Sakamoto club he presided over was small but active,

7 A detailed account of his biography is given by Smith (2007: 114-116). 
organizing trips to historical spots connected to Sakamoto. The club with bar also attracted people with a passing interest in Sakamoto. During my evening at the club, a group of salarymen visited who were interested in Sakamoto but had not yet become fan club members.

This fan club in Kyoto was obviously less about historical accuracy than celebrating Sakamoto as a contemporary pop star. Neither the president nor the members had any problems with merchandise and other forms of Sakamoto commercialization. On the contrary, they proudly collected merchandise in the bar and used it to signify their belonging. However, the bar itself was not based on the hope of commercializing Sakamoto. The president had ended his career as an influential shop owner in downtown Kyoto to live his life "Sakamotostyle." Thus, the bar and the Sakamoto club closely followed the pattern of Japanese fan clubs, as analyzed in Kelly's book Fanning the Flames. However, a typical fan club of a pop band seeks to install itself as a mediator between fans and the band itself, and successful fan clubs offer a means for their leaders to make a living through the club. The rewards for the most active clubs are therefore twofold: they can be economically independent and at the same time play the role of intermediaries between the band and the fans - a form of basking in reflected glory.

In the case of Sakamoto fan clubs, however, the basking in reflected glory is replaced by another aspect. Since their hero is dead, fans cannot seek to be close to him but only retrace his steps at historical sites. Nevertheless, the president and a few other interviewees mentioned that, to some extent, they had oriented their lifestyle and philosophy according to their interpretation of Sakamoto. It is not how close they are to their idol that indicates their success as a fan, but the partial modeling of their lives after Sakamoto.

Smith (2007) has also found various instances of the fans' passion for Sakamoto in Kyoto. At the cemetery where Sakamoto is buried, fans place their wishes written on pieces of cardboard next to his grave. They see Sakamoto not only as a role model and want to be like him, but also see him as a personal advisor. Fans - which now include many young people as well as older salarymen - find Sakamoto a great inspiration. However, for these people, it is most often not the real Sakamoto from history that inspires them but the character from the novels, TV series, and mangas. This popular image of Sakamoto has by far outlived the historical persona.

\section{Conclusion: Sakamoto in context}

Sakamoto Ryōma has been introduced in this paper as a Japanese "realm of memory" following Pierre Nora's concept of lieux de mémoire. I wanted to show 
that Sakamoto constitutes a very lively and important layer of popular historical memory in contemporary Japan. Even though it is crucial to analyze the "memories" associated with historical hotspots such as Yasukuni Shrine and the Nanjing Massacre, this layer also deserves attention. Since it is so popular, we cannot start exploring the Japanese lieux de mémoire if phenomena such as Sakamoto are ignored. This paper has shown that Sakamoto is not just a historical person, dead and forgotten, but is also "real" and "present" in Japan. Millions of people enjoy reading about Sakamoto in novels and mangas, and watching characterizations of him on television. Some have even formed fan clubs to keep his memory alive.

Therefore, an overview of Sakamoto's "current status" adds to the ongoing discussion on how memory unfolds in Japan, a discussion that has been often narrowed down in Western research to the question of how ultra-nationalism and the 15-year-long war have been remembered in Japan. However, the overall picture is much more complex. Analyzing Sakamoto as a "realm of memory" helps us to understand two points. First, Sakamoto's case is strongly connected to those realms of memory that feature prominently in Western research. The posthumous popularity of Sakamoto has been dictated by his usefulness as a democratic role model, a herald of modernity, and a naval hero. But Sakamoto as a realm of memory also has its dark sides, a fact that should caution current fans as to their hero's multifacetedness and problematic sides. Turning him into a modernist, a rebel, and a true democrat is not an inevitable interpretation based on his historical biography. However, had Sakamoto not been disassociated from naval war heroism, he would likely have been forgotten after 1945. Thus, examples like Sakamoto help us to see how discussions on dark periods of Japanese history cross boundaries and dictate realms of memory in general.

This in turn facilitates a broader understanding of memory in postwar Japan beyond the narrow focus on realms such as Yasukuni Shrine. It is easy to criticize the role and significance of Yasukuni Shrine; however, Sakamoto is a much less clear-cut case, which nevertheless is strongly bound up with the memory of 1931 to 1945 in current Japan, albeit much more indirectly than Yasukuni. The novels of Shiba Ryōtarō can only be understood from the perspective of disconnecting Meiji modernism from the slide into militarism and ultra-nationalism in the Shōwa era, and portraying Sakamoto as the embodiment of a bright, modern history.

The complexity of various intersecting realms of memory now becomes evident. Through Sakamoto's "realm", much can be learned about how memory entangles and conceals the dark spots of history. In addition, the case of Sakamoto also demonstrates how deeply memory influences everyday lives in Japan, and even partly remodels them. Thus, looking at popular realms of memory in 
Japan eventually opens up new possibilities. A Japanese version of Les lieux de mémoire - as suggested by Saaler and Schwentker, but with a much broader scope - would allow one to see how heroes such as Sakamoto Ryōma, Saigō Takamori, Katsu Kaishu, as well as other "realms", have been interpreted throughout the last 150 years of modern nation building in Japan. Japanese realms of memory covering the whole ground of memory surely would be warmly appreciated by pundits and the book market, but also by critical historians.

\section{Bionote}

PD Dr. Christian Tagsold is research fellow at the Institute for Modern Japan of Heinrich Heine University Dusseldorf, Germany. He has published on sports in Japan, Japanese gardens in the West, Japanese diasporas worldwide, aging society, and welfare.

\section{References}

Aida, Yūji. 1986. Rekishi shōsetsu no yomigata: Yoshiwara Eiji kara Shiba Ryōtarō made [The art of reading historical novels: From Eiji Yoshiwara to Ryōtarō Shiba]. Kyoto: PHP Kenkyūsho.

Amikura, Toshimune. 2010. Tōykō no Ryōmakai o tasunete [Visiting the Ryōma gathering in Tokyo]. Tōykōjin 25(8). 74-79.

Brandt, Susanne, Christoph Cornelissen, Lutz Klinkhammer \& Wolfgang Schwentker (eds.). 2003. Erinnerungskulturen: Deutschland, Italien und Japan seit 1945. Frankfurt: Fischer.

Buruma, Ian. 1994. The wages of guilt: Memories of war in Germany and Japan. New York: Farrar, Straus, Giroux.

Compagnon, Antoine. 1997. Marcel Proust's remembrance of things past. In Pierre Nora \& Lawrence D. Kritzman (eds.), Realms of memory: Rethinking the French past, Vol. 2 Traditions, 211-247. New York: Columbia University Press.

François, Etienne \& Hagen Schulze (eds.). 2001. Deutsche Erinnerungsorte, 3 vols. Munich: C.H. Beck.

Hakoishi, Hiroshi. 1994. Sakamoto Ryōma no ningenzō o megutte [Examining the image of Sakamoto Ryōma]. Rekishi Hyōron 53. 45-52.

Hamamoto, Hiroshi. 1995 [1943]. Kaientai. In Shōroku Matsui (ed.), Hamamoto Hiroshi: Kōchi-ken shōwa-ki shōsetsu meisaku-shū [Hamamoto Hiroshi: Collection of Shōwa period masterpieces from Kōchi Prefecture], 211-469. Kōchi: Kōchi Shinbun Kigyō.

Hongo, Jun. 27 April 2010. Sakamoto, the man and the myth. The Japan Times. http://search.japantimes.co.jp/cgi-bin/nn20100427i1.html (last accessed 31 August 2012). Irokawa, Daikichi. 1992. Rekishi no hōhō [The method of history]. Tokyo: Iwanami Shoten. 
Itō, Chiyū. 1930. Sakamoto Ryōma to Nakaoka Shintarō [Sakamoto Ryōma and Nakaoka Shintarō]. Tokyo: Heibonsha.

Jansen, Marius B. 1961. Sakamoto Ryōma and the Meiji Restoration. Princeton, NJ: Princeton University Press.

Kaku, Kōzō. 1993. Sakamoto Ryōma no miryoku-gaku [The science of Sakamoto Ryōma's charm]. Tokyo: Kōdansha + $\alpha$ bunko.

Kelly, William W. (ed.). 2004. Fanning the flames: Fans and consumer culture in contemporary Japan. Albany, NY: State University of New York Press.

Konishi, Shirō, Takeshi Yamamoto, Fumio Etō, Saichirō Miyaji \& Kijūrō Hirotani (eds.). 1988. Sakamoto Ryōma jiten [Sakamoto Ryōma dictionary]. Tokyo: Shinjinbutsu Ōraisha.

Le Goff, Jacques. 1998. Reims, city of coronation. In Pierre Nora \& Lawrence Kritzman (eds.), Realms of memory: Rethinking the French past, Vol. 3 - Symbols, 193-252. New York: Columbia University Press.

Mayama, Seika. 1928. Sakamoto Ryōma. Tokyo: Yananagi Kaeru Shoten.

Nakamura, Masanori. 2009. "Saka no ue no kumo" to Shiba rekishikan ["Clouds over the slope" and Shiba's notion of history]. Tokyo: Iwanami Shoten.

Narita, Ryūichi. 2003. Shiba Ryōtarō no bakumatsu meiji: "Ryōma ga yuku" to "Saka no ue no kuто” о уоти [Shiba Ryōtarō's end of the Edo period and Meiji: Reading "Ryōma moves ahead" and "Clouds over the slope"]. Tokyo: Asahi Shimbunsha.

Narita, Ryūichi. 2009. Sengo shisōka toshite Shiba Ryōtarō [Shiba Ryōtarō as postwar thinker]. Tokyo: Chikuma Shobō.

Niehaus, Andreas \& Christian Tagsold (eds.). 2012. Sport, memory and nationhood in Japan: Remembering the glory days. New York: Abingdon.

Nora, Pierre. 1989. Between memory and history: Les lieux de mémoire. Representations 26. 7-24.

Nora, Pierre \& Lawrence Kritzman (eds.). 1996. Realms of memory: Rethinking the French past, Vol. 1 - The construction of the French past. New York: Columbia University Press.

Nora, Pierre \& Lawrence Kritzman (eds.). 1997. Realms of memory: Rethinking the French past, Vol. 2 - Traditions. New York: Columbia University Press.

Nora, Pierre \& Lawrence Kritzman (eds.). 1998. Realms of memory: Rethinking the French past: Vol. 3 - Symbols. New York: Columbia University Press.

Ozaki, Hotsuki. 1976. Rekishi bungaku-ron [Treatise of history literature]. Tokyo: Kōdansha.

Pfister, Gertrud. 2011. Lieux de mémoire/sites of memories and the Olympic Games: An introduction. In Andreas Niehaus \& Christian Tagsold (eds.), Sport, memory and nationhood in Japan: Remembering the glory days, 10-28. Routledge: Abingdon.

Saaler, Sven \& Wolfgang Schwentker (eds.). 2008. The power of memory in modern Japan. Folkestone, UK: Global Oriental.

Sakazaki, Shiran. 1883. Kanketsu senri no koma [The sweat and blood of a genius]. Tokyo: Shunyōdō.

Saotome, Mitsugu. 1971. Sakamoto kitta otoko [The man who stabbed Sakamoto]. Tokyo: Bungeisha.

Shimaoka, Akira. 1965. Isetsu Sakamoto Ryōma [A different view of Sakamoto Ryōma]. Tokyo: Sainichi Shobō.

Smith, Henry. 2006. The media and politics of Japanese popular history: The case of the Akō Gishi. In James C. Baxter (ed.), Historical consciousness, historiography and modern Japanese values, 75-97. Kyoto: International Research Center for Japanese Studies.

Smith, Henry. 2007. Sakamoto Ryōma in Kyoto: Getting in personal touch with the past in Heisei Japan. In Martin Colcutt, Mikio Katō \& Ronald P. Toby (eds.), Japan and its 
worlds: Marius B. Jansen and the internationalization of Japanese studies, 103-118. Tokyo: I-House Press.

Tagsold, Christian. 2000. Fotografie = shashin? Zur fotografischen Wahrnehmung in Japan [Photography = shashin? On photographic perception in Japan]. In Julia Schmitt, Christian Tagsold, Hans-Diether Dörfler, Volker Hirsch \& Beate Rabe (eds.), Fotografie und Realität: Fallstudien zu einem ungeklärten Verhältnis, 123-146. Opladen: Leske \& Budrich.

Tsuka, Kōhei. 1990. Bakumatsu junjō-den: Ryōma o kitta onna [The legend of the pure heart of the late Tokugawa shogunate]. Toyko: Kakuwa Shoten.

Tsuka, Kōhei. 1991. Ryōma-den: Seishun-hen [The legend of Ryōma: Youth volume]. Tokyo: Kakuwa Shoten.

Tsuka, Kōhei. 1992. Ryōma-den: Yabō-hen [The legend of Ryōma: Aspiration volume]. Tokyo: Kakuwa Shoten.

Tsuka, Kōhei. 1994. Ryōma-den: Kesshin-hen [The legend of Ryōma: Determination volume]. Tokyo: Kakuwa Shoten.

Ueda, Atsuko. 2005. The production of literature and the effaced realm of the political. Journal of Japanese Studies 31(1). 61-88.

Vovelle, Michel. 1998. La Marseillaise: War or peace. In Pierre Nora \& Lawrence Kritzman (eds.), Realms of memory: Rethinking the French past, Vol. 3 - Symbols, 29-76. New York: Columbia University Press.

Werner, Michael. 2001. Heinrich Heine. In Etienne François \& Hagen Schulze (eds.), Deutsche Erinnerungsorte, Vol. 1, 484-502. Munich: C.H. Beck.

Winock, Michael. 1998. Joan of Arc. In Pierre Nora \& Lawrence Kritzman (eds.), Realms of memory: Rethinking the French past, Vol. 3 - Symbols, 433-482. New York: Columbia University Press. 